\title{
Correlative tomography of exceptionally preserved Jurassic ammonite implies hyponome-propelled swimming
}

\section{Lesley Cherns ${ }^{1 *}$, Alan R. T. Spencer ${ }^{2,3}$, Imran A. Rahman ${ }^{3,4}$, Russell J. Garwood ${ }^{3,5}$, Christopher Reedman", ${ }^{1,6}$ Genoveva Burca ${ }^{7,8}$, Martin J. Turner ${ }^{9}$, Neville T. J. \\ Hollingworth ${ }^{10}$, and Jason M. Hilton ${ }^{11}$}

${ }^{1}$ School of Earth and Environmental Sciences, Cardiff University, Cardiff, UK

${ }^{2}$ Department of Earth Science and Engineering, Imperial College London, London, UK

${ }^{3}$ Earth Sciences Department, Natural History Museum, London, UK

${ }^{4}$ Oxford University Museum of Natural History, University of Oxford, Oxford, UK

${ }^{5}$ Department of Earth and Environmental Sciences, University of Manchester, Manchester, UK

${ }^{6}$ Jurassic Coast Trust HQ, Bridport, Dorset, UK

${ }^{7}$ ISIS Facility, Rutherford Appleton Laboratory, Didcot, UK

${ }^{8}$ Faculty of Science and Engineering, University of Manchester, Manchester, UK

${ }^{9}$ Department of Computer Science, University of Manchester, Manchester, UK

${ }^{10}$ Science and Technology Facilities Council, Swindon, UK

${ }^{11}$ School of Geography, Earth and Environmental Sciences, University of Birmingham, Birmingham, $U K$

*E-mail: cherns@ cardiff.ac.uk 


\begin{abstract}
The extreme rarity of soft tissue preservation in ammonoids has meant there are open questions regarding fundamental aspects of their biology. We report an exceptionally preserved Middle Jurassic ammonite with unrivalled information on soft body organization interpreted through correlative neutron and X-ray tomography. 3D-imaging of muscles and organs of the body mass for the first time in this iconic fossil group provides key insights into functional morphology. We show that paired dorsal muscles withdrew the body into the shell, rather than acting with the funnel controlling propulsion as in Nautilus. This suggests a mobile, retractable body as a defence strategy and necessitates a distinct swimming mechanism of hyponome propulsion, a trait that we infer evolved early in the ammonoid-coleoid lineage.
\end{abstract}

\title{
INTRODUCTION
}

Ammonites are iconic fossils fundamental to Mesozoic biostratigraphy, yet surprisingly little is known about their soft tissues and, hence, their biology. In fossil cephalopods, exceptional taphonomic pathways led to soft tissue preservation in some Jurassic coleoids through phosphatization or carbonization (Allison, 1988; Wilby et al., 2004; Klug et al., 2015). By contrast, in contemporaneous ammonoids soft part anatomy is primarily inferred from muscle attachment scars inside the shell (Mironenko, 2014) and hard parts housed in the buccal mass and associated with feeding (Keupp and Mitta, 2013; Klug and Lehmann, 2015; Smith et al. 2021); indigestible (skeletal) remnants suggest a crop and stomach (Jäger and Fraaye, 1997). The only known soft tissues from Jurassic ammonites are fragments of mantle and possibly gills in a cadocerid (Mironenko, 2015) and detached, flattened body masses of jaws and organs outside perisphinctid shells (Klug et al., 2021). The digestive tract and buccal mass are best 
known from flattened Late Cretaceous heteromorph baculitids (Klug et al., 2012). Potentially significant taphonomic biases that inhibited soft part preservation in ammonoids and fossil nautiloids include purportedly weak, less preservable musculature than fast-swimming predatory coleoids (Maeda and Seilacher, 1996), post-mortem buoyancy (Kear et al. 1995), and the impact of ammonia in soft tissues, important for buoyancy control in coleoids and Nautilus (Clements et al., 2017). Musculature is thus mostly interpreted through comparison with extant Nautilus (Doguzhaeva and Mutvei 1996). Substantive three-dimensional preservation of ammonite soft parts is hitherto unreported.

We document the rare preservation of the soft body mass of a Middle Jurassic macroconch ammonite, Sigaloceras (Catasigaloceras) enodatum. This unique specimen (Fig. 1) has 3D-preserved soft tissues in the inner body chamber and siphuncle. The specimen was figured previously (Klug and Lehmann 2015, fig. 12.5) but not interpreted; subsequent investigation using both laboratory- and synchrotron-based X-ray analyses was unable to discriminate soft tissues. Using a new integrative approach of combined non-destructive neutron tomography and X-ray microtomography, we visualize and interpret this anatomy in 3D (Fig. 2; see Movie S1 in Supplemental Material ${ }^{1}$ ). This is the first extensive 3D-preservation of ammonite soft tissues in the body chamber documented through CT (cf. Hoffmann et al. 2021). We identify previously inferred muscle blocks (Doguzhaeva and Mutvei 1996; Mironenko 2014) and match them to attachment scars directly, using their structure and orientation to suggest function. We also elucidate the unusual, exceptional taphonomy, which may identify similar paleontological contexts elsewhere.

\section{MATERIALS AND METHODS}


Internal mold split from a macroconch shell of $S$. (C.) enodatum Nikitin, 1881 from the Lower Callovian (Calloviense Biozone) Kellaways Sand Member of Claydon Pike pit, Fairford, Gloucestershire, UK. Specimen deposited at National Museum Wales, Cardiff;

NMW.2002.69G.1. See Supplemental Material ${ }^{1}$ for detail of geology and methods.

Photography in both transmitted and reflected artificial white light used a Nikon D700. ESEM was undertaken at the Natural History Museum, London. EDX used a Cambridge Instruments SEM in the School of Earth and Environmental Sciences, Cardiff University.

Neutron tomography was performed at the IMAT beamline of ISIS Neutron and Muon Spallation Source. X-ray microtomography was undertaken using a Nikon Metrology XTek XT H 225 at the University of Manchester.

A combined 3D model was created in DragonFly 4.1 (https://www.theobjects.com/dragonfly/index.html) by importing both X-ray and neutron tomography datasets. Structures were manually segmented into contiguous blocks of soft tissues. Some are individual elements of the anatomy (e.g. 'hr' and 'sc' in Fig. 2), others represent multiple elements pressed together (e.g. 'cr' in Fig. 2). Figures and videos were generated in Blender 2.82 (https://www.blender.org).

Data generated during this study are available on Zenodo: https://doi.org/10.5281/zenodo.5118537

\section{RESULTS AND MORPHOLOGICAL INTERPRETATION}

The body chamber (Fig. 1; diameter $59.7 \mathrm{~mm}$ ) occupies $\sim 240^{\circ}$, with slight breakage at the aperture. The internal mold comprises translucent, amber-colored calcite filling camerae and the inner (posterior) body chamber $\left(\sim 120^{\circ}\right)$; micritic sediment with shell fragments fills the outer 
(anterior) body chamber (Figs. 1, 2A). The shell (detached) and septa are recrystallized to pale, opaque calcite. Within the calcite of the inner part of the body chamber and close $(\sim 1 \mathrm{~mm})$ inside the right lateral surface of the mold, a thin $(\sim 1 \mathrm{~mm})$, dense, brown to black, uneven layer (Fig. 1C, D) extends across $\sim 90^{\circ}$ towards the contact with the sediment-filled, outer body chamber. With additional transmitted light (Fig. 1A, B), this layer appears as a large and dense, lobed inner mass, elongate along the whorl, flanked dorsally and ventrally by less solid dark 'strands'. These diverge anteriorly from in front of two flanges of a black 'arrowhead'-shaped mass, directed posteriorly.

The phosphatized ventral siphuncular cord is evident throughout the phragmocone ('s', red in Fig. 2A-D). Ventral and ventrolateral muscle attachments are indicated by shallowly indented, bilobed outlines on the mold (Fig. 1B, G), in front of the siphuncle. Interpretation of the arrowhead-shaped block ('sc', orange in Fig. 2A-D, K, N, Movie S1) as siphuncular cord muscles now detached among the soft body mass would accord with a ventral scar for a muscle/ligament controlling circumsiphonal invagination in the body wall (Jordan, 1968) (Fig. 1B; = ventral muscle scar of Doguzhaeva and Mutvei, 1996).

We interpret the dense central mass as cephalic retractor muscles around a $\mathrm{u}$-shaped digestive system and muscular buccal mass comparable to living cephalopods (Nautilus, coleoids) ('cr', blue in Fig. 2A-D, K, L, N, O). 'Strands' extending dorsally from the main mass are interpreted as remnants of paired dorsal muscles of the cephalic retractors ('dp', green in Fig. 2A-D, F). Shallow dorsal scars are evident on the mold (Figs 1B, 3B).

Lying ventral to the cephalic retractors are the hyponome retractor muscles ('hr' pink, in Fig. 2A-E, L, O; Mironenko 2014). Isolated blocks oriented towards the ventrolateral scars (Fig. 1F, G) on both sides of the body chamber and inclined away from the main soft body mass we 
propose are fragments of hyponome retractors ('vl', yellow in Fig. 2A-E). A shallow anterior lateral sinus on the mold (Fig. 1B), not present in Nautilus, may also relate to hyponome muscle attachment to the mantle (Mironenko, 2014).

Fringing the main mass, at the abrupt inclined contact of calcite against the sediment infill (Fig. 1C), is an irregular, ridged? layer ('lj', purple in Fig. 2A, C, I, M, P) we interpret as the relict aptychus (lower jaw). We suggest this, preserved in close to life orientation (Tanabe et al., 2015), originally blocked the body chamber, perhaps associated with an unmineralized upper jaw ('uj' or its musculature: green block lying proximately dorsal and central in the body chamber in Fig. 2D, J), sealing and preventing further ingress of sediment into the body chamber. The limited preservation of a plate suggests an at least predominantly organic composition; this genus has only a very thin and infrequently preserved calcitic layer coating a chitinous lower jaw (Keupp and Mitta, 2013; Parent and Westermann, 2016).

\section{DISCUSSION}

Given the exceptional rarity of ammonite soft-tissue preservation, the taphonomy of this unique specimen is noteworthy. The ammonite was buried rapidly - evidenced by the ammonitebivalve coquinas of limestone concretions - with the body retracted into the inner body chamber. This became sealed by the jaw(s) and sediment infilled the outer body chamber before significant soft tissue decay. The jaw remained in approximately life orientation (Fig. 1C, E), but not in the anterior position known from other ammonites (Doguzhaeva and Mutvei, 1991; Cope and Sole, 2000) and Nautilus. The oblique, geopetal contact between sediment and translucent calcite infill

(Fig. 1E) shows the specimen lay on its side, likely buried beneath sediment. The soft body collapsed onto the body chamber floor, and anoxic conditions within this sealed 
microenvironment promoted authigenic phosphate mineralization. As such, catastrophic burial combined with the sealed body chamber created an exceptional taphonomic environment.

In the siphuncle, apatite (Supplemental Material ${ }^{1}$ ) microspheres cover lightly striated surfaces (Fig. 3D), and penetrate tissue (Fig. 3E, F). The neutron tomography scan resolution is insufficient to determine if such fine details are also preserved in the muscles, but similar attenuation values of siphuncle and muscles (Fig. 2G) indicate likely similar chemical compositions, suggesting phosphatization affected muscles prior to siphuncle rupture. Such preservation through early diagenetic phosphate mineralization usually occurs in soupy, argillaceous sediments (Allison, 1988; Wilby et al., 2004). The Kellaways Sand Member is a firm, coarse sediment, neither rich in organic clays nor pyrite to suggest an anoxic or restricted sediment-water interface. The source of phosphate was probably internal, from partial decomposition of soft tissues in the anoxic, reducing microenvironment within the sealed body chamber (Allison, 1988). Incomplete preservation included loss of the entire tentacle mass trapped within the shell. Lack of detail in preservation possibly relates to ammonia in soft tissues buffering against fall in pH (Clements et al., 2017).

Correlative neutron and X-ray tomography (Fig. 2, Movie S1) reveals the soft parts in 3D. Thin and only weakly muscular mantle tissues that enveloped the soft body are patchily preserved at best. Dorsal muscles for the cephalic retractors ('dp' and 'cr' in Fig. 2A-D, F), not present in Nautilus, potentially enabled retraction deep into the body chamber for defence. The body chamber in ammonoids is generally longer than in Nautilus and fossil nautiloids (Doguzhaeva and Mapes, 2015). R etreat into the shell may have compensated for the lack of a hood to close the aperture (Monks and Young, 1998; Mironenko, 2014) and apparent lack of an ink sac, a defence feature of modern and fossil coleoids (Glass et al., 2012; Klug et al., 2019). 
This arrangement of cephalic retractor musculature implies that the ammonoid swimming mechanism differed from Nautilus, which relies on laterally attached, powerful cephalic retractor muscles forming a roof around the soft parts to generate propulsion together with contraction of funnel wings (Wells and O’Dor, 1991; Doguzhaeva and Mutvei, 1996; Neil and Agnew, 2018). Mironenko (2014) proposed, based on morphological and taphonomic features of muscle scars and sinuses, that only the hyponomic retractors attached to large ventrolateral muscle scars in ammonoids. Taken with our interpretation of the dorsal muscles, and the large hyponomic retractors ('hr' in Fig. 2A-D), we suggest ammonite propulsion relied on a ventral muscular hyponome - comparable to many coleoids but not primarily controlled by contraction of a muscular mantle, and as hypothesized for ammonoids on theoretical grounds (Jacobs and Landman, 1993). Sanders and Ward (1994) suggest constraints of the shell made hyponome extension and external operation likely.

In conclusion, through preserved soft tissues described with the aid of a novel imaging approach and interpreted through reference to previous work on muscle scars (Mironenko 2014), we suggest that paired dorsal muscles in ammonoids provided a retraction mechanism for defence and a hyponome-based swimming mechanism. Hyponome evolution was considered an autapomorphy of the stem cephalopod lineage before divergence of extant nautiloids and coleoids (Engeser, 1996), the exact timing of which is debated (Kröger et al., 2011). The muscle arrangement described here places ammonites in an intermediate position. Our specimen hints that an important role for the hyponome in propulsion evolved early in the bactritoidammonoid-coleoid lineage, and was not restricted to crown coleoids with internalized shells. We recommend that other ammonites preserved with in situ jaws are investigated by correlative nondestructive neutron and X-ray tomography for soft tissue preservation to provide further insights. 


\section{ACKNOWLEDGMENTS}

We thank Chris Jones (Natural History Museum, London) and Julia Behnsen (Manchester University) for technical help, Neale Monks, Royal Mapes and John Cope for discussion, and Christian Klug and anonymous reviewers for comments on a previous version of this manuscript. We gratefully acknowledge the Science and Technology Facilities Council (STFC) for access to neutron beamtime at ISIS, and provision of sample preparation on the IMAT beamline under experiment 1810821, and access to the Diamond Light Source on Beamline I12 under experiment EE9244. EPSRC UK funded the Henry Moseley X-ray Imaging Facility through the Royce Institute for Advanced Materials (grants EP/F007906/1, EP/F001452/1, EP/I02249X, EP/M010619/1, EP/F028431/1, EP/M022498/1 and EP/R00661X/1).

\section{REFERENCES CITED}

Allison, P.A., 1988, Phosphatized soft-bodied squids from the Jurassic Oxford Clay: Lethaia, v. 21, p. 403-410, https://doi.org/10.1111/j.1502-3931.1988.tb01769.x.

Clements, T., Colleary, C., De Baets, K., and Vinther, J., 2017, Buoyancy mechanisms limit preservation of coleoid cephalopod soft tissues in Mesozoic Lagerstätten: Palaeontology, v. 60 , p. 1-14, https://doi.org/10.1111/pala.12267.

Cope, J.C.W., and Sole, D.T.C., 2000, Ammonite jaw apparatuses from the Sinemurian (Lower Jurassic) of Dorset and their taphonomic relevance: Journal of the Geological Society, v. 157, p. 201-205, https://doi.org/10.1144/jgs.157.1.201. 
Doguzhaeva, L.A., and Mutvei, H., 1991, Organization of the soft body in Aconeceras

(Ammonitina), interpreted on the basis of shell morphology and muscle-scars:

Palaeontographica Abteilung A, v. 218, p. 17-33.

Doguzhaeva, L., and Mutvei, H., 1996, Attachment of the body to the shell in ammonoids, in N.

H. Landman, N.H., Tanabe, K., and Davis, R.A. eds., Ammonoid Paleobiology: New York, USA, Springer, p. 43-63.

Doguzhaeva, L.A., and Mapes, R.H. 2015, The body chamber length variations and muscle and mantle attachments in ammonoids, in Klug, C., Korn, D., De Baets, K., Kruta, I., and Mapes, R.H., eds., Ammonoid Paleobiology: From Anatomy to Ecology: Dordrecht, Netherlands, Springer, p. 545-584.

Engeser, T., 1996, The position of the Ammonoidea within the Cephalopoda, in N. H. Landman, N.H., Tanabe, K., and Davis, R.A. eds., Ammonoid Paleobiology: New York, USA, Springer, p. 3-19.

Glass, K., Ito, S., Wilby, P.R., Sota, T., Nakamura, A., Bowers, C.R., Vinther, J., Dutta, S., Summons, R., Briggs, D.E.G., Wakamatsu, K., and Simon, J.D., 2012, Direct chemical evidence for eumelanin pigment from the Jurassic period: Proceedings of the National Academy of Sciences of the United States of America, v. 109, p. 10218-10223, https://doi.org/10.1073/pnas.1118448109.

Hoffmann, R., Morón-Alfonso, D., Klug, C., and Tanabe, K., 2021, Ammonoid soft tissue remains revealed by computed tomography: Swiss Journal of Palaeontology, v. 140, no. 1, p. 1-14.

Jacobs, D.K. and Landman, N.H., 1993: Nautilus - a poor model for the function and behavior of ammonoids? Lethaia, v. 26, p. 101-111, 
Jäger, M., and Fraaye, R., 1997, The diet of the Early Toarcian ammonite Harpoceras falciferum: Palaeontology, v. 40, p. 557-574.

Jordan, R., 1968, Zur Anatomie mesozoischer Ammoniten nach den Strukturelementen der Gehäuse-Innenwand: Beihefte zum Geologischen Jahrbuch, v. 77, p. 1-64.

Kear, A. J., Briggs, D. $\quad$ E.G., Donovan, D. $\quad$ T. 1995. Decay and fossilization of nonmineralized tissue in coleoid cephalopods. Palaeontology, v. 38, p. 105-132.

Keupp, H., and Mitta, V., 2013, Cephalopod jaws from the Middle Jurassic of central Russia: Neues Jahrbuch für Geologie und Paläontologie - Abhandlungen, v. 270, p. 23-54, https://doi.org/10.1127/0077-7749/2013/0356.

Klug, C., and Lehmann, J., 2015, Soft part anatomy of ammonoids: Reconstructing the animal based on exceptionally preserved specimens and actualistic comparisons, in Klug, C., Korn, D., De Baets, K., Kruta, I., and Mapes, R.H., eds., Ammonoid Paleobiology: From Anatomy to Ecology: Dordrecht, Netherlands, Springer, p. 507-529.

Klug, C., Riegraf, W., and Lehmann, J., 2012, Soft-part preservation in heteromorph ammonites from the Cenomanian-Turonian Boundary Event (OAE 2) in north-west Germany: Palaeontology, v. 55, p. 1307-1331, https://doi.org/10.1111/j.1475-4983.2012.01196.x.

Klug, C. Fuchs, D., Schweigert, G., Röper, M., and Tischlinger, H., 2015, New anatomical information on arms and fins from exceptionally preserved Plesioteuthis (Coleoidea) from the Late Jurassic of Germany: Swiss Journal of Palaeontology, v. 134, p. 245-255, https://doi.org/10.1007/s13358-015-0093-y.

Klug, C., Landman, N.H., Fuchs, D., Mapes, R.H., Pohle, A., Guériau, P., Reguer, S., and Hoffmann, R., 2019, Anatomy and evolution of the first Coleoidea in the Carboniferous: Communications Biology, v. 2, 280, https://doi.org/10.1038/s42003-019-0523-2. 
Klug, C., Schweigert, G., Tischlinger, H., and Pochmann, H., 2021, Failed prey or peculiar necrolysis? Isolated ammonite soft body from the Late Jurassic of Eichstätt (Germany) with complete digestive tract and male reproductive organs: Swiss Journal of Palaeontology, v. 140, 3, https://doi.org/10.1186/s13358-020-00215-7.

Kröger, B., Vinther, J., and Fuchs, D., 2011, Cephalopod origin and evolution: A congruent picture emerging from fossils, development and molecules: Bioessays, v. 33, p. 602-613, https://doi.org/10.1002/bies.201100001.

Maeda, H., and Seilacher, A., 1996, Ammonoid taphonomy in N. H. Landman, N.H., Tanabe, K., and Davis, R.A. eds., Ammonoid Paleobiology: New York, USA, Springer, p. 543-578.

Mironenko, A.A., 2014, The soft-tissue attachment scars in Late Jurassic ammonites from Central Russia: Acta Palaeontologica Polonica, v. 60, p. 981-1001, https://doi.org/10.4202/app.00041.2013.

Mironenko, A.A., 2015, Soft-tissue preservation in the Middle Jurassic ammonite Cadoceras from Central Russia: Swiss Journal of Palaeontology, v. 134, p. 281-287, https://doi.org/10.1007/s13358-015-0082-1.

Monks, N., and Young, J.R., 1998, Body position and the functional morphology of Cretaceous heteromorph ammonites: Palaeontologia Electronica, v. 1, 1A, https://doi.org/10.26879/98001.

Neil, T. R., and Askew, G. N., 2018, Swimming mechanics and propulsive efficiency in the chambered nautilus: Royal Society Open Science, v. 5, 170467. http://dx.doi.org/10.1098/rsos.170467.

Nikitin, S., 1881, Der Jura der Umgegend von Elatma, Part 1: Nouveaux mémoires de la Société impériale des naturalistes de Moscou, v. 14, p. 86-136. 
Parent, H., and Westermann, G.E.G., 2016, Jurassic ammonite aptychi: Functions and evolutionary implications: Swiss Journal of Palaeontology, v. 135, p. 101-110, https://doi.org/10.1007/s13358-015-0102-1.

Sanders, W. B., and Wards, P. $\quad$ D., 1994, Nautilus is not a model for the function and behavior of ammonoids: Lethaia Seminar, v. 27, p. 47-48.

Smith, C. $\quad$ P. A., Landman, N. H., Bardin, J., and Kruta, I., 2021, New evidence from exceptionally "well-preserved" specimens sheds light on the structure of the ammonite brachial crown: Scientific Reports v. 11, 11862.

Tanabe, K., Kruta, I., and Landman, N. H., 2015, Ammonoid buccal mass and jaw apparatus, in Klug, C., Korn, D., De Baets, K., Kruta, I., and Mapes, R. H., eds., Ammonoid paleobiology: From anatomy to ecology, Springer, p. 429-484.

Wells, M.J., and O’Dor, R.K., 1991, Jet propulsion and the evolution of the cephalopods: Bulletin of Marine Science, v. 49, p. 419-432.

Wilby, P.R., Hudson, J.D., Clements, R.G., and Hollingworth, N.T.J., 2004, Taphonomy and origin of an accumulate of soft-bodied cephalopods in the Oxford Clay Formation (Jurassic, England): Palaeontology, v. 47, p. 1159-1180, https://doi.org/10.1111/j.00310239.2004.00405.x.

Wippich, M.G.E., and Lehmann, J. 2004, Allocrioceras from the Cenomanian (mid-Cretaceous) of the Lebanon and its bearing on the palaeobiological interpretation of heteromorphic ammonites: Palaeontology, v. 47, p. 1093-1107, https://doi.org/10.1111/j.00310239.2004.00408.x.

\section{FIGURE CAPTIONS}


Figure 1. Internal mold of S. enodatum showing preserved remnants of internal soft body features, and their interpretation. A, right lateral view in transmitted and reflected light showing dark, opaque material within calcite-filled inner body chamber , and sediment-filled outer body chamber, and $\mathrm{B}$, interpretation. $\mathrm{C}$, right lateral view in reflected light, and $\mathrm{D}$, detail, showing steeply inclined aptychus separating calcite fill from sediment in outer chamber; note relatively poor definition of dark body within calcite cf. A. E, oblique left lateral view in reflected light showing aptychus separating sediment and calcite fills; geopetal calcite outside aptychus indicates post-depositional orientation. F, G, virtual reconstruction in posterior view showing muscle scars. Scale bar: A, B, F, G = $10 \mathrm{~mm} ; \mathrm{C}, \mathrm{E}=12 \mathrm{~mm}$; D = $6 \mathrm{~mm}$. Boxes in A, E $=$ Figs $3 \mathrm{~A}, \mathrm{~B}$.

Figure 2. Virtual reconstruction (A, B, E, F, I, J), interpretive line drawings (C, D) and slice images (G, H, K-P). A, C, E, F, I, J, right lateral view. B, D, posterior view. E, detail of fragments of muscle bases for ventrolateral muscles to hyponome retractor scars. F, detail of dorsal muscles to cephalic retractors. G, neutron tomography slice showing similar attenuation of siphuncle $($ mean $=0.22)$ and cephalic retractor muscles $($ mean $=0.24)$. H, X-ray tomography slice. I, detail of aptychus. J, detail of upper jaw or its musculature. K, L, N, O, neutron tomography slices without $(\mathrm{K}, \mathrm{L})$ and with $(\mathrm{L}, \mathrm{O})$ segmentation masks showing siphuncular cord muscles and hyponome retractor muscles. M, P, X-ray tomography slice without (M) and with (P) segmentation mask showing aptychus. Abbreviations: cr, cephalic retractor muscles, ushaped muscular digestive system, buccal mass; dp, dorsal muscles to cephalic retractors; hr, hyponome retractor muscles; lj, lower jaw (aptychus); s, siphuncle; sc, siphuncular cord muscles; 
uj, upper jaw or its musculature; vl, fragments of muscle bases for ventrolateral muscles to hyponome retractor scars. Scale bar: A-D, G, H $=5 \mathrm{~mm}$; E, F, I, K-P = $2 \mathrm{~mm} ; \mathrm{J}=1 \mathrm{~mm}$.

Figure 3. SEM images of S. enodatum. A-C, muscle and mantle scars (uncoated specimen in ESEM). A, oblique LL view showing shallow, incised dorsal muscle scar ('s') anterior to annular elevation (mantle attachment zone ' $m$ ') in front of last septum. Rough zone and low anterior ridge of annular elevation evident also in previous camerae. B, oblique RL view showing dorsal muscle scar (arrowed). C, detail of B (box) showing fine ridges parallel to anterior margin of muscle scar. D-F, Apatite of siphuncle fill (coated specimen in SEM). D, lightly striated surface (arrowed; muscle fibres?) pseudomorphed by microspheres. E, F, transverse surface of D showing aggregated clusters of microspheres penetrating through tissue. Scale bars: A, B = 1 $\mathrm{mm} ; \mathrm{C}=0.1 \mathrm{~mm} ; \mathrm{D}-\mathrm{F}=5 \mu \mathrm{m}$.

${ }^{1}$ GSA Data Repository item 202Xxxx, details of material, geological setting, methods and movie showing virtual reconstruction of S. enodatum, available online at www.geosociety.org/pubs/ft20XX.htm, or on request from editing@geosociety.org. 
Figure 1

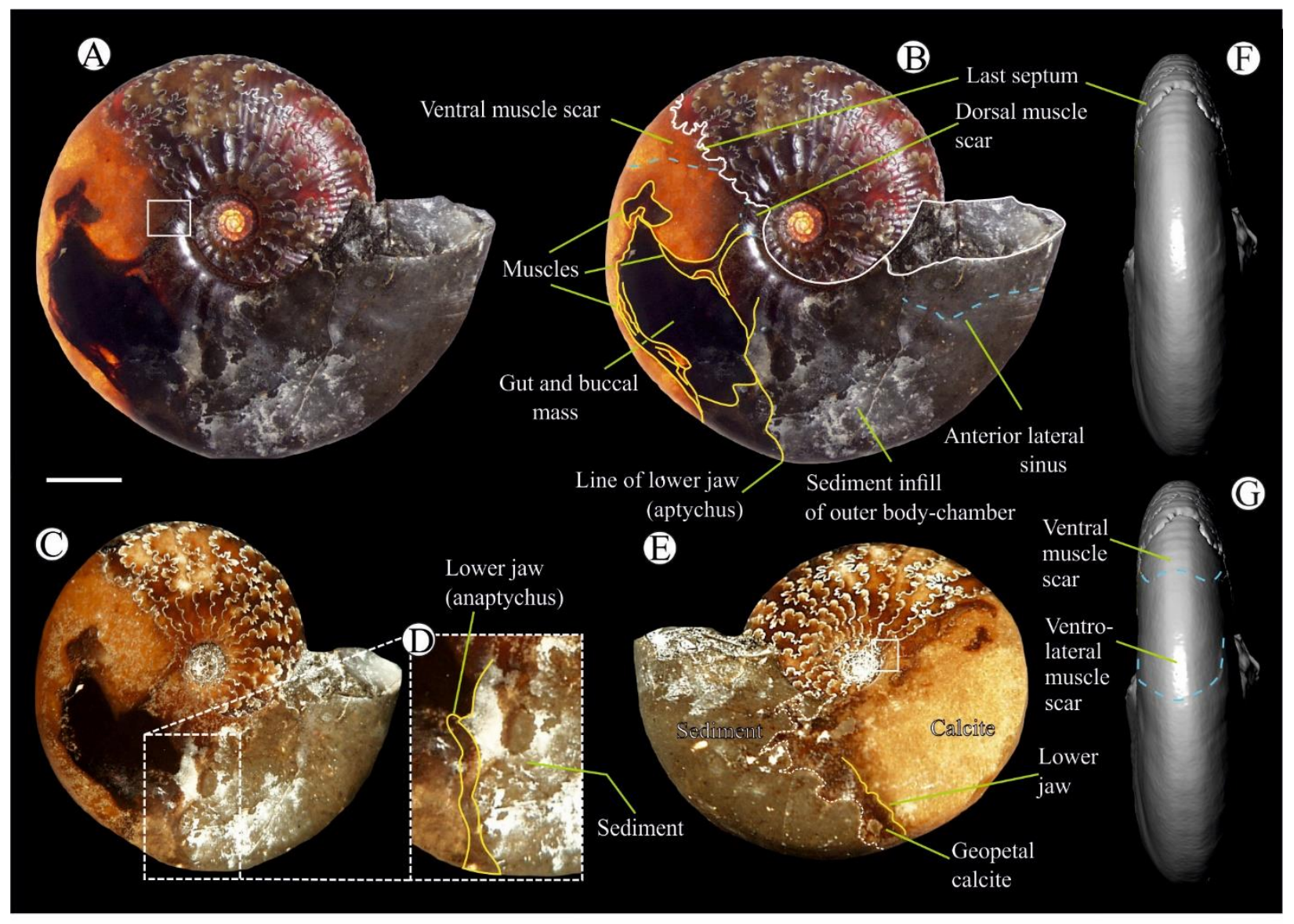


Figure 2
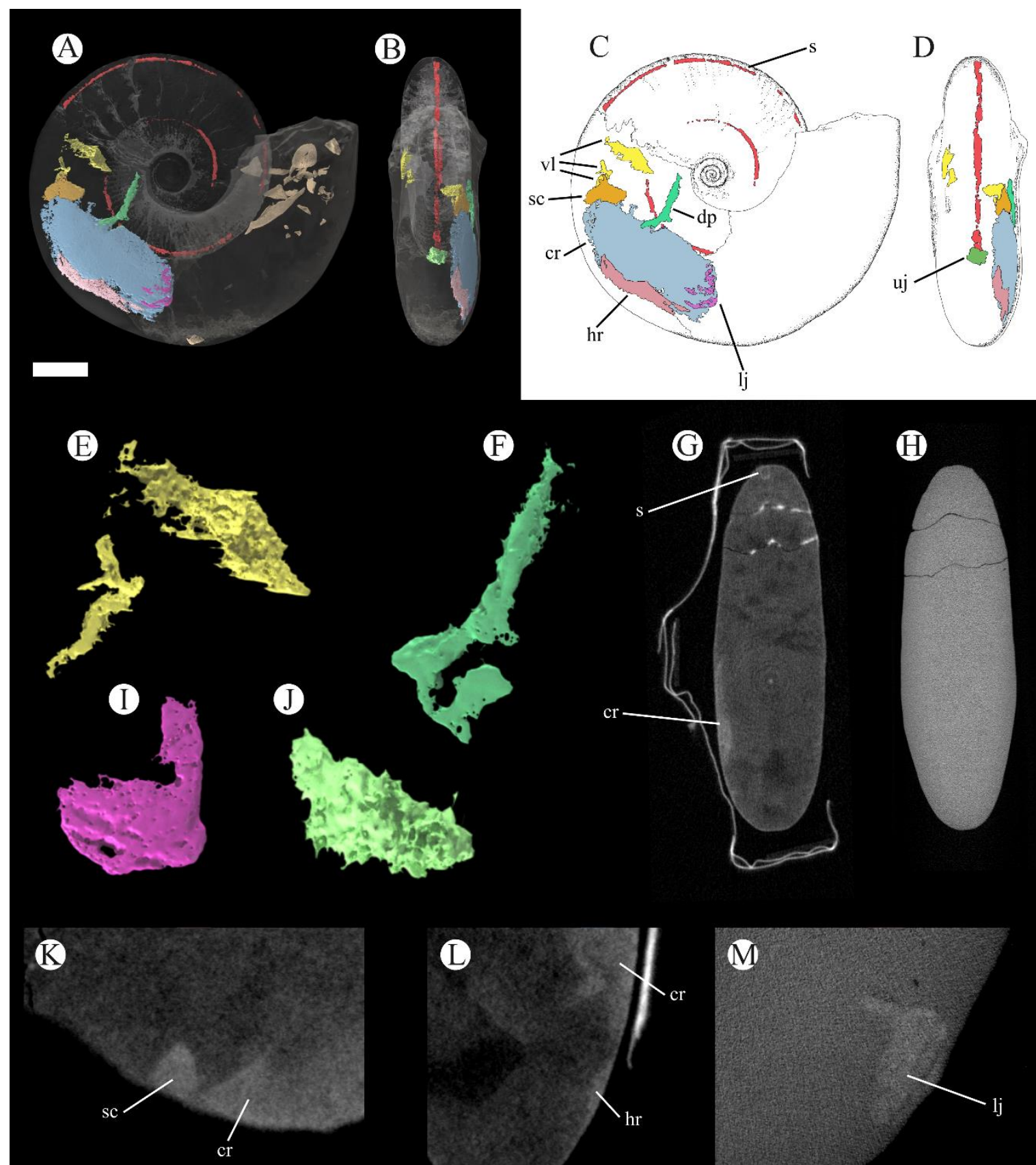

(H)
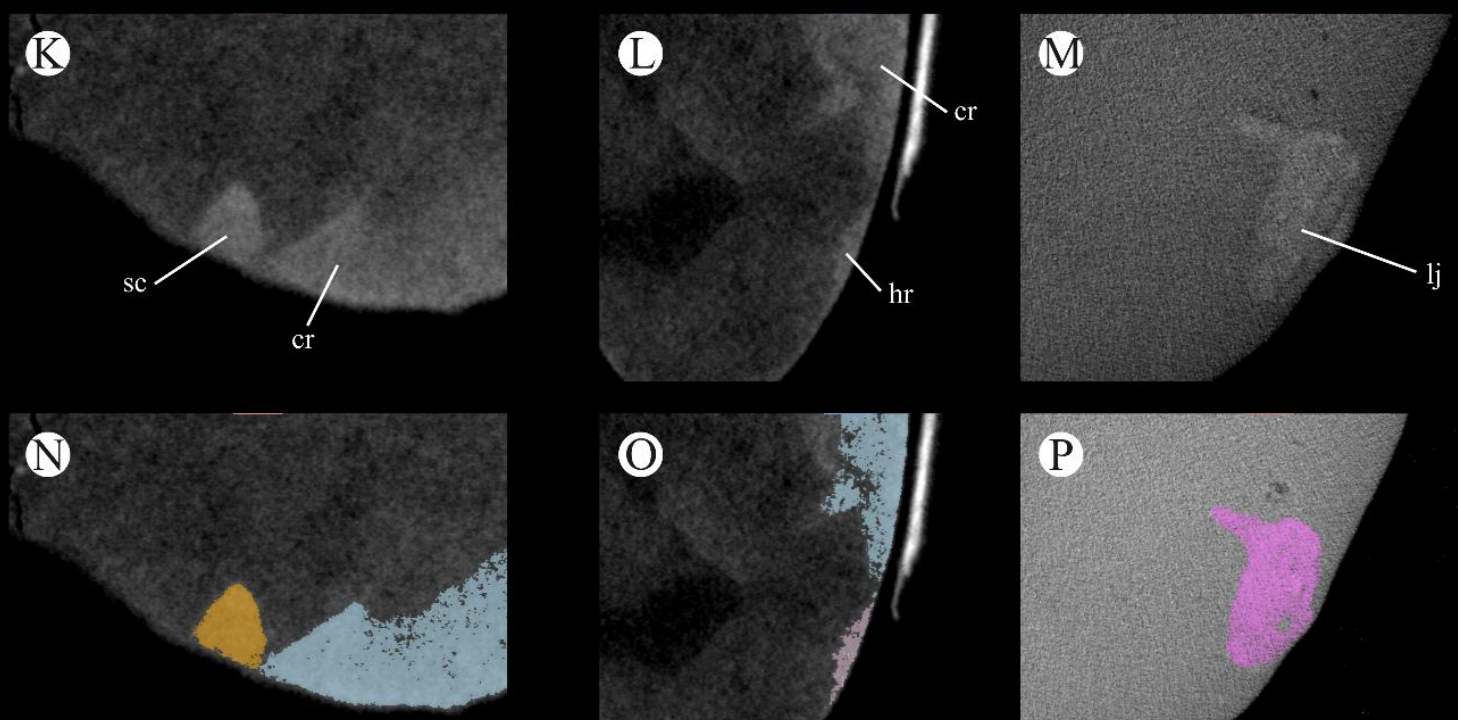

O

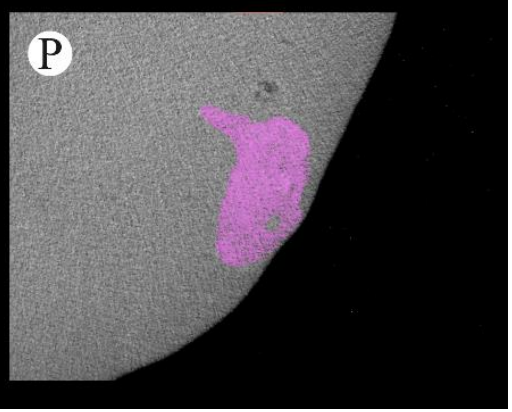


Figure 3
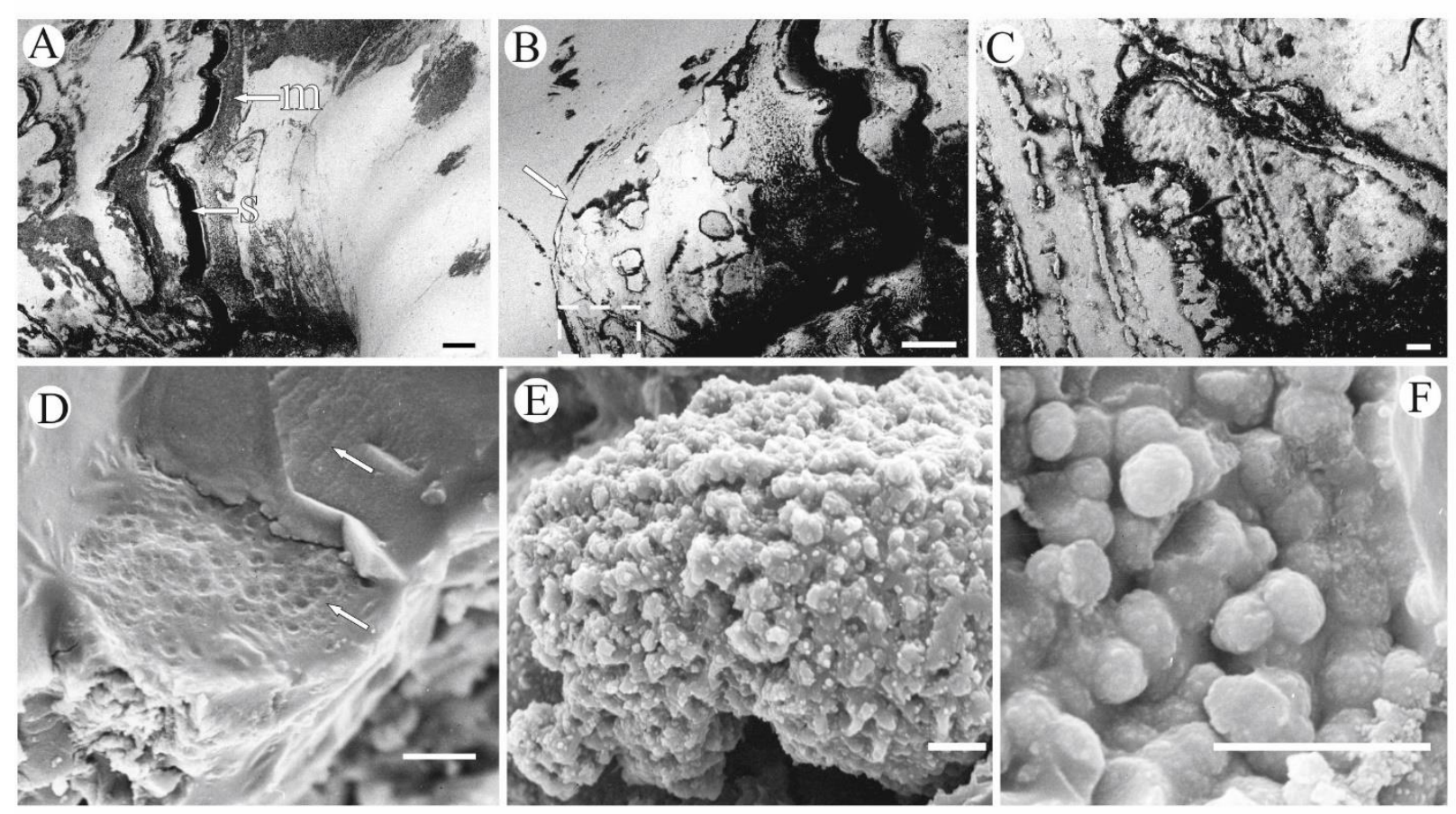


\section{GSA Data Repository 202Xxxx}

Correlative tomography of exceptionally preserved Jurassic ammonite implies hyponome-propelled swimming

Lesley Cherns", Alan R. T. Spencer, Imran A. Rahman, Russell J. Garwood, Chris Reedman, Genoveva Burca, Martin J. Turner, Neville T. J. Hollingworth, and Jason Hilton

*E-mail: cherns@ cardiff.ac.uk 


\section{Material}

A single specimen of Sigaloceras (Catasigaloceras) enodatum Nikitin, 1881 from the Lower Callovian (Calloviense Biozone) Kellaways Sand Member (Fig. S1) of Colne Gravel, Claydon Pike pit, Fairford, Gloucestershire, UK (site now flooded). WGS 30U 587216.566 5728069.106. The internal mold has been split away from the shell, with two halves of the shell being retained in two blocks of consolidated matrix. The relatively small specimen is mature, as it shows approximation of the last two sutures and uncoiling of the umbilical seam, while loss of ornament on the body chamber is consistent with a macroconch (Callomon, 1955; Fig. S2). A shallow anterior lateral sinus apparent on the mold (Mironenko 2014; Fig. 1) is distinct from the deep lateral sinus of some ammonoids (Doguzhaeva and Mutvei 1996). The specimen is deposited at the National Museum Wales, Cardiff. Accession no. NMW.2002.69G.1. 


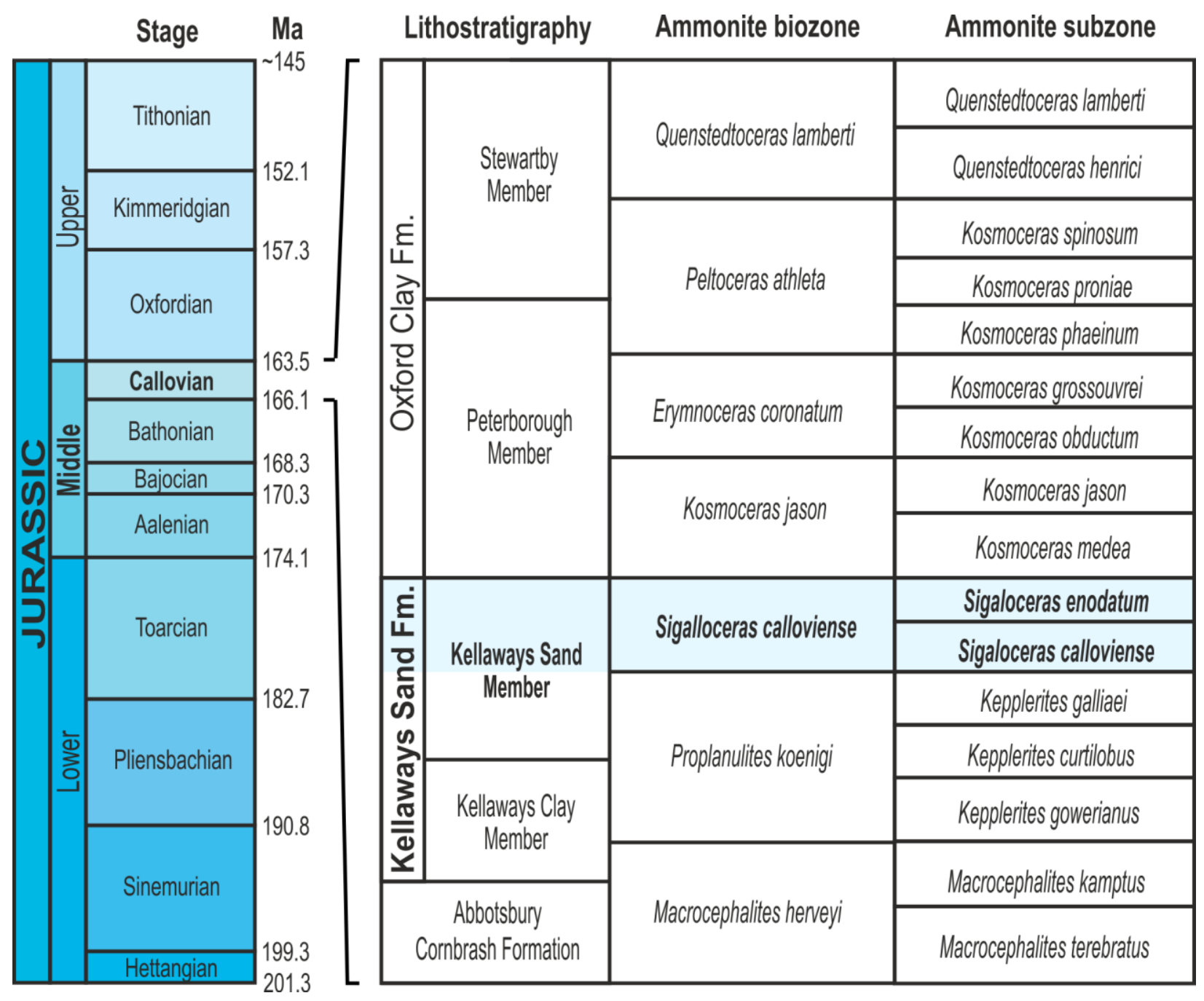

Fig. S1. Stratigraphic framework for the Jurassic of the UK. Modified from Spencer et al. (2017). 


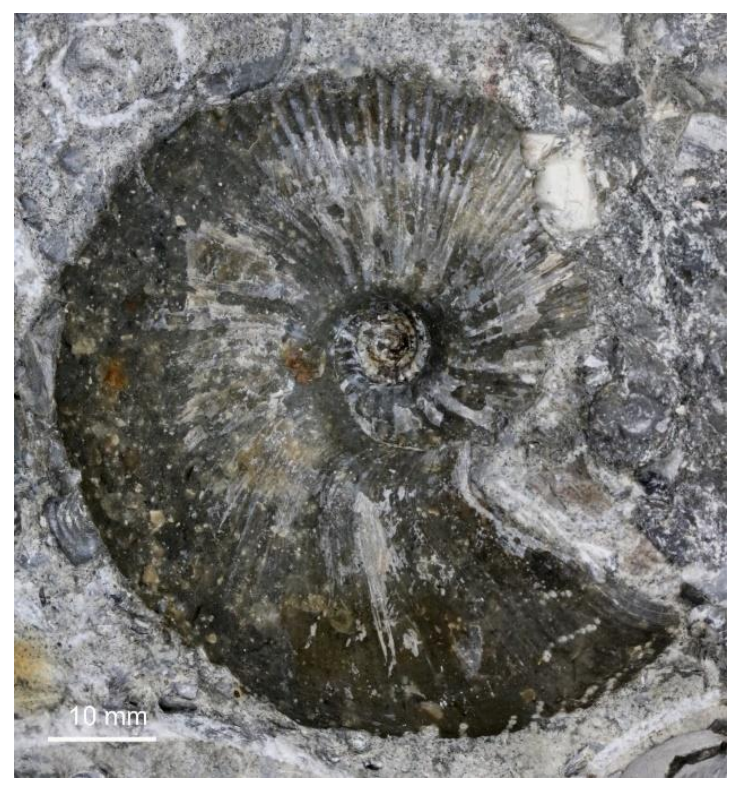

Fig. S2. Ammonite block (counterpart); note uncoiling of umbilical seam and loss of ornament on body chamber.

\section{Geological setting}

The Claydon Pike pit site consists of poorly cemented, calcareous sands, including laterally impersistent calcareous sandstones, and abundant shelly lenses and diagenetic sandy limestone concretions that have diverse, molluscan-rich assemblages. This unit represents a period of basinward, transgressive spread of coarse siliciclastic facies close to the edge of the London Brabant massif, deposited in shallow and periodically high energy environments. Within the concretion containing the S. enodatum macroconch, many shells are disarticulated and fragmented, and they are closely packed, locally imbricated and winnowed in a micritic to microsparitic, sandy matrix with abundant woody debris. Winnowed shelly accumulates created by storm disturbance affected the shelly benthos, but ammonites were also buried rapidly under prograding shell sand ripples. The S. enodatum specimen shows no evidence of prolonged exposure (e.g., scavenging, shell encrustation, reworking of sediment fill), nor of exhumation 
from elsewhere and re-deposition, as the sedimentary fill in the apical parts of the body-chamber is the same as the matrix of the concretion.

\section{Methods}

The internal mold was photographed using both transmitted and reflected photography in artificial white light with a Nikon D700. Images were color corrected and balanced using GIMP 2.8 (https://www.gimp.org). Scanning electron microscopy (SEM) was undertaken using an environmental chamber SEM at the Natural History Museum, London. In addition, energy dispersive X-ray spectroscopy (EDX) was performed using a Cambridge Instruments SEM in the Department of Earth Sciences, Cardiff University.

Neutron tomography was performed at the IMAT beamline (Burca et al., 2018) of ISIS Neutron and Muon Spallation Source, UK, using an optical camera box equipped with a Zyla sCMOS 4.2 Plus camera (www.andor.com), 135 mm lens from Nikon, a 45 degree optical mirror and a $6 \mathrm{LiF} / \mathrm{ZnS}$ scintillator with a thickness of $80 \mu \mathrm{m}$. For a field-of-view of $120 \times 120 \mathrm{~mm}^{2}$, an effective pixel size of $58 \mu \mathrm{m}$ was used. A total of 1801, 30 second projections were acquired over $360^{\circ}$ rotation. Projections were reconstructed as two-dimensional slices using Octopus Imaging Software (https://octopusimaging.eu) (Rahman et al., 2018). X-ray microtomography was undertaken using a Nikon Metrology XTek XT H 225 at the University of Manchester, UK, with a $0.5 \mathrm{~mm}$ copper filter, $145 \mathrm{kV}$ voltage and $85 \mu \mathrm{A}$ current, capturing 6000 projections on a $3192 \times 2296$ detector. Projections were reconstructed using Nikon Metrology NV's XT 5.1.4.3 software (https://www.nikonmetrology.com). The resultant image stack $(3190 \times 3192 \times 1151)$ had a voxel size of $0.0196 \mathrm{~mm}$. 
A combined three-dimensional model was created in DragonFly 4.1

(https://www.theobjects.com/dragonfly/index.html). Both the X-ray and neutron tomography datasets were imported into the software. The X-ray microtomography dataset, which reveals the internal and external shell structure at high resolution (19 $\mu \mathrm{m}$ voxels), was used to register and align the neutron tomography dataset in three dimensions, which is of lower resolution (58 $\mu \mathrm{m}$ voxels. This allowed both sets of data to be viewed together. Attenuation mechanisms differ between the incident radiations, picking out different details. Thus, by combining areas within the 3D space of differing attenuation, either X-ray or neutron, we were able to individually mask regions of interest (ROIs). These regions were volume rendered by the software as manipulable false-colour 3D objects. The ROIs were subsequently processed to remove any islands of 9-50 voxels in total number using the 6-connected method. Contour meshes were generated from these ROI's using a threshold of 50 and linear sampling in the $\mathrm{x}, \mathrm{y}$, and $\mathrm{z}$ of either 1,2 , or 4 (dependent of the initial size of the ROI). The resultant meshes were then iteratively smoothed five times, using laplacian smoothing, before being exported to an STL format file as binary. Figures and videos of the model were generated in Blender 2.82 (https://www.blender.org). Data generated during this study are available on Zenodo: https://doi.org/10.5281/zenodo.5118538

Photographs were acquired with a Nikon D90 digital single-lens reflex camera. A total of 143 photographs were taken at a resolution of $4288 \times 2848$ pixels. Photographs were masked with GIMP 2.8 to remove the background surrounding the specimen using the fuzzy, scissor and lasso select tools, then exported as PNG files. Photogrammetry was performed using Agisoft Metashape 1.5.3 (https://www.agisoft.com), importing masks from the alpha png layer. A sparse point cloud was then generated, incorrectly positioned points manually cleaned, a dense cloud created and then meshed and exported in .ply format. 
Movie S1. Virtual reconstruction of S. enodatum. Movie available at:

\section{Ammonite_video_29Sep_21.mkv}

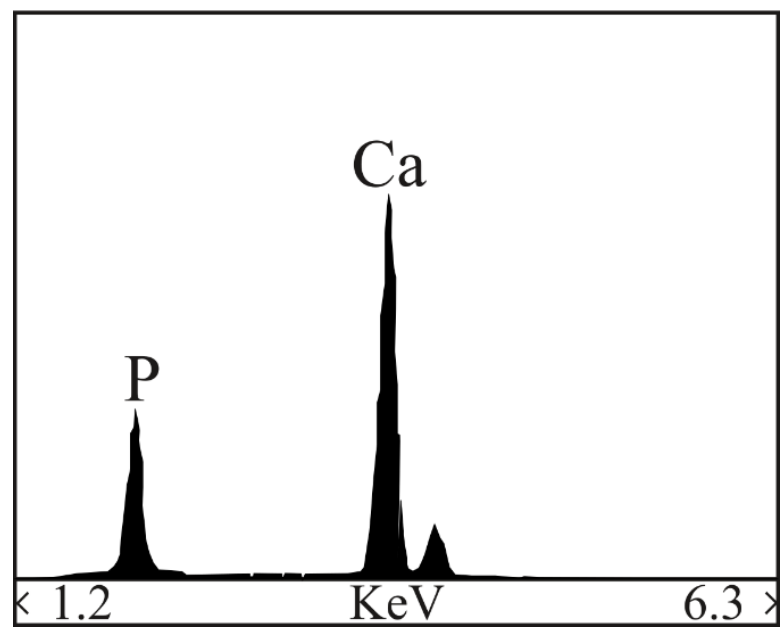

Figure S3. Energy dispersive X-ray spectrum of siphuncle of S. enodatum, indicating apatitic composition of dark fill.

\section{REFERENCES CITED}

Burca, G., Nagella, S., Clark, T., Tasev, D., Rahman, I.A., Garwood, R.J., Spencer, A.R.T., Turner, M.J., and Kelleher, J.F., 2018, Exploring the potential of neutron imaging for life sciences on IMAT: Journal of Microscopy, v. 272, p. 242-247, https://doi.org/doi:10.1111/jmi.12761.

Callomon, J.H., 1955, The ammonite succession in the Lower Oxford Clay and Kellaways beds at Kidlington, Oxfordshire, and the zones of the Callovian Stage: Philosophical Transactions of the Royal Society B, v. 239, p. 215-264, https://doi.org/10.1098/rstb.1955.0010. 
Rahman, I.A., Garwood, R.J., Burca, G., and Spencer, A.R.T., 2018, Applying neutron tomography to exceptionally preserved fossils with poor X-ray contrast: STFC ISIS Neutron and Muon Source, https://doi.org/10.5286/ISIS.E.RB1810821.

Spencer, A.R.T., Garwood, R.J., Rees, A.R., Raine, R.J., Rothwell, G.W., Hollingsworth, N.T.J., and Hilton, J., 2017, New insights into Mesozoic cycad evolution: An exploration of anatomically preserved Cycadaceae seeds from the Jurassic Oxford Clay biota: PeerJ, v. 5, e3723, https://doi.org/10.7717/peerj.3723. 